AUSTRALIAN

WELFARE

Historical Sociology 


\title{
AUSTRALIAN WELFARE
}

\section{Historical Sociology}

\author{
Edited by \\ RICHARD KENNEDY \\ School of Sociology, \\ The University of New South Wales
}


Copyright (C) 1989 Richard Kennedy and contributors

All rights reserved.

No part of this publication

may be reproduced or transmitted

in any form or by any means,

without permission.

First published 1989 by

THE MACMILLAN COMPANY OF AUSTRALIA PTY LTD

I07 Moray Street, South Melbourne 3205

6 Clarke Street, Crows Nest 2065

Associated companies and representatives

throughout the world

National Library of Australia

cataloguing in publication data

Australian welfare: historical sociology.

Includes index.

ISBN 978-1-349-11083-4 ISBN 978-1-349-11081-0 (eBook)

DOI 10.1007/978-1-349-11081-0

I. Social welfare-Australia - History. 2. Public

welfare-Australia-History. 3. Australia-Social

policy-History. I. Kennedy, Richard, 1936-

36I'.994

Set in Plantin by

Macmillan India Ltd, Bangalore 


\section{Contents}

Notes on the Contributors vii

Preface xii

Introduction:

I What We Argue: A Survey I

II Liberal Welfare History: A Discredited Paradigm 9

III On Historical Sociology I4

Richard Kennedy

\section{Comparisons}

Chapter I World Economic Crises and the Welfare State in Australia Ted Wheelwright 28

Chapter 2 Welfare and Equality in Capitalist Societies: How and Why Australia was Different

Francis Castles 56

Chapter 3 The Network of Surveillance: The Power of Official Enquiries into Poor Relief Provision in New South Wales, 1898 and $1984 \quad$ Rosemary Berreen and Michael Wearing 74

\section{Interpretations}

Chapter 4 'In Fractured Times': The Accord and Social Policy Under Hawke, 1983-87 Rob Watts 104

Chapter 5 The Labourist Tradition and the Reforming Imagination Peter Beilharz 132

Chapter 6 Sex and Money in the Fiscal Crisis

Sheila Shaver I54

Chapter 7 War, Women and Welfare

Lorraine Wheeler 172 
Chapter 8 Class, 'Welfare' and Capitalism: The Role Aborigines have Played in the State-building Processes in Northern Territory History

Gordon Briscoe 197

Chapter 9 Aborigines and the Politics of Alcohol

Peter Khoury 216

\section{Advocacies}

Chapter ro New Directions in Disability: A Report on the Progress of the 'Deserving Poor' Foyce Evans 242

Chapter I I 'Normalising Aliens': The Australian Welfare State and the Control of Immigrant Settlement

Andrew fakubowicz 263

Chapter 12 Inequalities in Our Provisions for Young Children Tania Sweeney 304

Chapter 13 Ageing in Australia Gisela Kaplan 329

Chapter I4 Working Girls in 'Wowserville': Prostitute Women in Sydney since $1945 \quad$ Roberta Perkins 362

Chapter 15 The Drunken Patriarch and His Family: A History of the Australian Feminist Response to Alcohol

Frances Lovejoy 390

Chapter I6 How Liberal Welfare History Constructs the Reformist Poor Richard Kennedy 399

Chapter I7 'Sailing to Byzantium': Whitlam's Welfare and the Australian Working Class Drew Cottle 408

Conclusion: The Welfare of the Working Class is the Task of the Working Class Mr Fustice (Fim) Staples 425

Abbreviations 450

Index 45 I 


\section{Notes on the Contributors}

PETER BEILHARZ has taught history, politics and sociology in Victorian high schools, at Monash University and Phillip Institute and has worked at Melbourne University. He now teaches social theory at La Trobe University, Melbourne. A frequent reviewer and contributor to local debate, he co-founded Thesis Eleven in I979. He has written widely on socialism and the labour movement, in works including Trotsky, Trotskyism and the Transition to Socialism (1987) and Labor's Accord (1988, with Rob Watts). At present he is working on a study of socialism and feasible utopias, and doing preliminary research on a full-length ideological history of Australian labourism.

ROSEMARY BERREEN teaches social welfare history and contemporary social welfare in the School of Social Work, University of New South Wales, Sydney. She is currently working on a doctoral thesis about illegitimacy in Sydney in the early I900s, and has published in the areas of institutional child welfare and social welfare education.

GORDON BRISCOE was born in the Northern Territory, the child of an Aboriginal mother and European father in a 'half-caste institution'. He prefers to be known as an 'Aboriginal person'. He holds a BA Honours History degree from the Australian National University, and is preparing to submit a Master's thesis. He took part in the foundation of the Aboriginal Medical Service, Redfern, and was a foundation member of the Aboriginal Legal Service. He also assisted in establishing the Central Australian Aboriginal Congress. At the moment, Mr Briscoe is the History Research Officer at the Australian Institute of Aboriginal Studies in Canberra.

FRANCIS CASTLES is Senior Research Fellow in Political Science at the Australian National University and was formerly Professor of Comparative Politics at the Open University in the United Kingdom. He is the author of numerous books and articles on compara- 
tive public policy and welfare, including The Working Class and Welfare (1985), a study of the historical origins of the welfare state in Australia and New Zealand. His most recent book is Australian Public Policy and Economic Vulnerability, which explores in greater detail many of the themes examined in his chapter.

DREW COTTLE, a child of the Sydney working class, left school early and completed his secondary education at night school. He has taught Australian welfare history at the University of New South Wales, where the Department of General Studies published his Capital Essays (1984). Cottle is now a refugee from mandarin History, marooned in the Community and Welfare Studies Department at the Macarthur Institute of Higher Education, Milperra, arguing for socialism with those who wish merely to police or Christianise the poor. He has published widely and is currently hewing a doctoral thesis at Macquarie University.

FOYCE EVANS was born in 1949, and lost her sight in her late teens. She graduated BA honours (1974) and $\mathrm{PhD}$ (1985) from the University of New England. Dr Evans has worked at the ABC, and now teaches media studies and Australian welfare history at the University of New South Wales. She is a member of the Australian Labor Party, and actively involved in the disabled persons' political movement.

ANDREW JAKUBOWICZ was born in Kings Cross and grew up in Bondi. His parents are Polish Jews, refugees, via China, from the Holocaust. He has worked variously at the Universities of New South Wales, Bradford and Wollongong; at the latter, he spent some time as Director of the Centre for Multicultural Studies. He has been a member of the Board of the Special Broadcasting Service (to which he was appointed, and from which he was removed, by the Labor government). He has been employed (in each case, only once) by government departments ostensibly worried about their inactivity on issues concerned with immigrants. His findings have either been suppressed or attacked by those governments: he is still naive enough to believe the truth will out. At present he is Principal Lecturer at the University of Technology, Sydney, teaching media and social policy.

GISELA KAPLAN gained her $\mathrm{PhD}$ from Monash University, and has been a Lecturer since 1983 , first at Monash and then at the University of New South Wales. Her main research interests are in the areas of migrant and women's issues. Apart from her work on 
migrant health and migrant ageing, she is at the present time completing a book on Western European feminism.

RICHARD KENNEDY is Senior Lecturer, School of Sociology, University of New South Wales. Much of his childhood was spent outside Melbourne pubs, waiting for an alcoholic father, not a bad training for a social historian/historical sociologist. He taught Australian history with Ian Turner at Monash in the late 1960s, in a course that emphasised twentieth century themes. Now he teaches in the fields of welfare history, historical sociology, oral history, and alcohol and society. Kennedy has edited Australian Welfare History: Critical Essays (1982, reprinted twice), and has written Charity Warfare: The Charity Organisation Society in Colonial Melbourne (1985), on the rise of Australian social work. A third manuscript, 'Dad Drinks': Memories and Reflections of Australians with Alcoholic Fathers (1984) is available only for limited circulation. His current research is directed towards a book on Australia, the alcoholic society.

PETER KHOURY has worked in the welfare field for a number of years. His chapter is based on research conducted for an Honours degree in Sociology at the University of New South Wales. He has taught Australian welfare in the Department of General Studies, at the same place; and now teaches sociology at the University of Technology, Sydney. He intends to begin work on a doctorate shortly.

$F_{R A N C E S}$ LOVEFOY, born in rural Queensland, gained Science and Economics degrees from the University of Queensland, and a M. Ag. Ec. degree from the University of New England. She has a long-term interest in women's issues and in the study of 'deviance'. Frances was elected Head of the School of Sociology, University of New South Wales, from 1985 to 1987 . She co-ordinates the MA in Women's Studies and has been active in setting up the Women's Studies' Centre. She is working on a book about women and alcohol.

RoberTa PERKINS was born in Adelaide in 1940. She has spent much time and effort in supporting the legal and social rights of oppressed minority groups. In 1983 she received funds from the Minister for Youth and Community Services to establish refuges for homeless trans-sexuals. In the same year she founded the Australian Prostitutes' Collective, which was granted funds from the New South Wales Department of Health in order to combat 
AIDS. Among her published works are two books: The 'Drag Queen' Scene (1983) and Being A Prostitute (1985).

SHEILA SHAVER is Senior Lecturer in the School of Behavioural Sciences (Sociology) at Macquarie University, Sydney. She spent I 988 on study leave at the City University of New York writing a book provisionally titled Whose Welfare State? Class, Gender and Community in the Australian Welfare State.

J. F. STAPLES is a BA, LLB of Sydney University, formerly of the Sydney Bar and now a Deputy President of the Australian Conciliation and Arbitration Commission, to which he was appointed by the Whitlam government in February 1975. He fell out of favour with the Fraser government, and has been kept in coventry by the Hawke government, as a mark of combined government, employer and union disapproval of some of his decisions and of his general analysis of the law concerning industrial relations. His public career has been beset by want of repentance.

TANIA SWEENEY is Principal Research Officer at the Social Welfare Research Centre, University of New South Wales. She has been involved in child and family welfare policy, planning and research for the last eleven years, prior to which she worked in the areas of community services and health research.

ROB WATTS teaches social theory and social policy at Phillip Institute of Technology, Melbourne. He is an editor of Thesis Eleven and of Historical Studies and has recently published The Foundations of the National Welfare State. He is currently involved in establishing a Community Development course for Victoria, and in re-thinking the economic agenda for Australia.

MICHAEL WEARING is a post-graduate Research Scholar in Sociology at the Social Welfare Research Centre, University of New South Wales. He has worked as a social worker with intellectually disabled people. His research interests are in the fields of public opinion, political anthropology and the Australian welfare state.

LORRAINE WHEELER works with the Council of Social Service of New South Wales as a Policy Analyst. For fourteen years she was a welfare practitioner before taking up University studies made possible by the Mature-Age Student Scheme. In 1985 Lorraine completed her PhD in Sociology, on the links between World War I, women and welfare. She is at present researching the nature 
and structure of the contemporary community services' labour market.

TED WHEELWRIGHT has been studying, teaching and researching political economy for forty years on five continents. A graduate of the University of St Andrews in Scotland, he has recently retired from the University of Sydney, where he was Associate Professor of Economics. He is the author, co-author and editor, of numerous books, the latest being, No Paradise for Workers: Capitalism and the Common People in Australia, 1788-1914, (with Ken Buckley), published by Oxford University Press in 1988. 


\section{Preface}

Australian Welfare: Historical Sociology, although designed as a text for a course I teacher in Australian Studies on the Historical Sociology of Australian Welfare, should also appeal to undergraduate students of Sociology, History, Social Work and Welfare Studies, as well as to general readers and radical scholars.

The project began on study leave in 1986 from the University of New South Wales. I am particularly grateful to Professor Bob Connell, first for his inspiration as Australia's leading historical sociologist, and additionally for a pleasant six months I spent as a Visiting Associate in Behavioural Sciences (Sociology) at Macquarie University.

Dr Eric Fry observed of my first book, edited for Macmillan, Australian Welfare History: Critical Essays (1982) that 'it made a sustained critical re-assessment of an entire field'. I have no quarrel with those busy publishers, and overworked teachers and librarians who refer to edited books of this kind as 'collections of readings'. However, the writers' collective has aimed to do more than merely aggregate readings. Two structural theses underlie every word in the book, though I do not intend to assist lazy readers and reviewers by stating here what they are!

Most of the contributors are either history or sociology-based, and each was given a brief to write about 8,000 words on the 'historical sociology' of their special area. Consequently, most of the chapters have either been especially written, or freshly rewritten, for the book, except for Mr Justice Staples' moving summation of his working philosophy, which first emerged as a speech at Clyde Cameron College, and is printed gloriously free of footnotes.

My thanks to Phyllis Kennedy; to Connie Benn; to Peter Khoury for research assistance; to Bernice Ryan and Karl Krebs for typing a chapter each; to Drew Cottle for tolerating a bullying editor; to Peter Debus for his patience; and to my tutors, Joyce Evans, Susan Hardy, Susan Keen, Jim Macken and Barbara Whiteman, for so much help. 
On 15 December 1985, I was invited to join the School of Sociology at the University of New South Wales. This book is dedicated (with the collective's consent) to Frances Lovejoy, Jarlath Ronayne, Sol Encel, John Milfull, Ann Daniel and Lois Bryson.

Richard Kennedy February 1988 